\title{
Optimizing the combustion processes of a small scale solid fuel-fired boiler
}

\author{
D. MENTES ${ }^{1}$, Z. SAJTI2 ${ }^{2}$ T. L. Koós ${ }^{3}$, Cs. PóLISKA ${ }^{4}$ \\ 1University of Miskolc, Institute of Energy and Quality, tuzdora@uni-miskolc.hu \\ 2University of Miskolc, Institute of Energy and Quality, tuzqkac@uni-miskolc.hu \\ 3University of Miskolc, Institute of Energy and Quality, koos.tamas@uni-miskolc.hu \\ ${ }^{4}$ University of Miskolc, Institute of Energy and Quality, tuzcsaba@uni-miskolc.hu
}

Abstract. Over the last decade, the public has been paying increasing attention to reducing greenhouse gas and acid rain emissions and reducing particulate matter, which is extremely harmful to health and the environment. To improve air quality, the European Commission has achieved a range of measures to reduce air pollutant emissions in the transport, heat and electricity, industrial and agricultural sectors.

In Hungary, the amount of gas and solid air pollutants from solid fuel combustion used by the public during the heating season represents a significant percentage of the total amount present in the atmosphere. In 2016, taking into the total emission, the 29\% of CO2 emissions; $85 \%$ of CO emissions; $75 \%$ of the particulate matter emissions and $21 \%$ of the NOx emissions were derived from households. It follows that the improvement of air quality can also be achieved by controlling the emissions of solid fuel combustion plants.

During our research we aimed to optimize the operation of a newly purchased TOTYA S18 boiler and a pilot pellet boiler. Operating the boilers in the correct mode minimizes air pollutant emissions, and the greater part of the heat generated is actually turns to heating the home, as with poor settings, a lot of heat leaves through the chimney. The data obtained during the tests can also be used to determine whether the boilers comply with the emission values set out in Commission Regulation (EU) 2015/1185.

\section{Introduction}

Over the last decade, the public has been paying increasing attention to reducing greenhouse gas and acid rain emissions and reducing particulate matter, which is extremely harmful to health and the environment. To improve air quality, the European Commission has achieved a range of measures to reduce air pollutant emissions in the transport, heat and electricity, industrial and agricultural sectors [1]. According to World Health Organization (WHO) and European Economic Area (EEA), this reduction in total emissions of air pollutants does not automatically lead to a similar reduction in air pollutant concentrations [2]. This view is also reinforced by the fact that, despite these measures, in a significant number of Central and Eastern European countries, including Hungary, the levels of air pollution exceed daily and annual limit value of particulate matter and nitrogen dioxide which are in the Directive 2004/107/EC and Directive 2008/50/EC. One of the reasons is residential solid fuel firing [1]. It can be read about in the literature that during winter the residential wood burning for heating is an important source of particles emissions [3] [4] [5] [6] [7]. 
As a result, the European Commission has issued the implementation of Commission Regulation (EU) 2015/1188 implementing Directive 2009/125/EC of the European Parliament and of the Council with regard to ecodesign requirements for local space heaters (Table 1). According to the expectations with this limitation, the number of emissions from households will be decreased and it will become much more controllable. However, households that have old types of firing equipment are typically financially unable to buy a new one.

\begin{tabular}{|c|c|c|c|c|c|}
\hline & Efficiency & \multicolumn{3}{|c|}{ Emission of pollutants (max) } \\
\cline { 4 - 6 } & $\begin{array}{c}\text { (min) } \\
{[\%]}\end{array}$ & $\begin{array}{c}\mathrm{PM} \\
{\left[\mathrm{mg} / \mathrm{m}^{3}\right]}\end{array}$ & $\begin{array}{c}\text { Gaseous } \\
\text { organic } \\
\text { compounds } \\
{\left[\mathrm{mg} / \mathrm{m}^{3}\right]}\end{array}$ & $\begin{array}{c}\mathrm{CO} \\
{\left[\mathrm{mg} / \mathrm{m}^{3}\right]}\end{array}$ & $\begin{array}{c}\mathrm{NO}_{\mathrm{x}} \\
{\left[\mathrm{mg} / \mathrm{m}^{3}\right]}\end{array}$ \\
\hline $\begin{array}{c}\text { open front solid fuel fired individual room } \\
\text { heating equipment }\end{array}$ & 30 & 50 & 120 & 2000 & 200 \\
\hline $\begin{array}{c}\text { solid fuel burning (other than pellet) } \\
\text { individual room heating equipment with a } \\
\text { closed combustion chamber }\end{array}$ & 65 & 40 & 120 & 1500 & 200 \\
\hline $\begin{array}{c}\text { pellet burning individual room heating } \\
\text { equipment with a closed combustion } \\
\text { chamber }\end{array}$ & 79 & 20 & 60 & 300 & 200 \\
\hline
\end{tabular}

Table 1. Limit values for the environmentally conscious design of solid fuel installations [8]

In Europe currently residential wood combustion is increasing because of rising fossil fuel prices but also due to climate change mitigation policies [3]. The combustion cycles were characterised by three main stages, namely ignition, flaming and smouldering. The ignition corresponds to the heating of the biomass followed by drying and initial steps of devolatilisation, without the existence of visible flame. The flaming stage is characterised by devolatilisation and combustion of volatiles and char during which a vigorous flame is observed. In the smouldering stage, the $\mathrm{O}_{2}$ concentrations in the flue gas start to increase and the temperatures in the combustion chamber decrease again [9] [10].

In comparison with coal, biomass has a much higher content of volatile matter; thus, the process of biomass combustion is dominated by devolatilisation and the gas-phase combustion of the volatiles. In general, the combustion of solid fuels emits a complex mixture of gaseous and particulate species: products from complete combustion $\left(\mathrm{CO}_{2}\right.$ and $\left.\mathrm{H}_{2} \mathrm{O}\right)$, products from incomplete combustion (e.g., CO, polycyclic aromatic hydrocarbons, particles), volatile organic compounds, nitrogen oxides etc. [10].

Many parameters are independent of the user impact the emissions and the thermal efficiency such as the chimney system and weather conditions. Combustion conditions (including fuel characteristic [11], combustion air supply setting [12] and the ignition technique [3]) have a great influence on the fine particle and gas emissions particularly from residential wood combustion appliances [13][14][15].

In Hungary, the amount of gas and solid air pollutants from solid fuel combustion used by the public during the heating season represents a significant percentage of the total amount present in the atmosphere. In 2016, taking into the total emission, the $29 \%$ of $\mathrm{CO}_{2}$ emissions; $85 \%$ of $\mathrm{CO}$ emissions; $75 \%$ of the particulate matter emissions and $21 \%$ of the $\mathrm{NO}_{\mathrm{x}}$ emissions was derived from households 
(Figure 1). It follows that the improvement of air quality can also be achieved by controlling the emissions of solid fuel combustion plants.

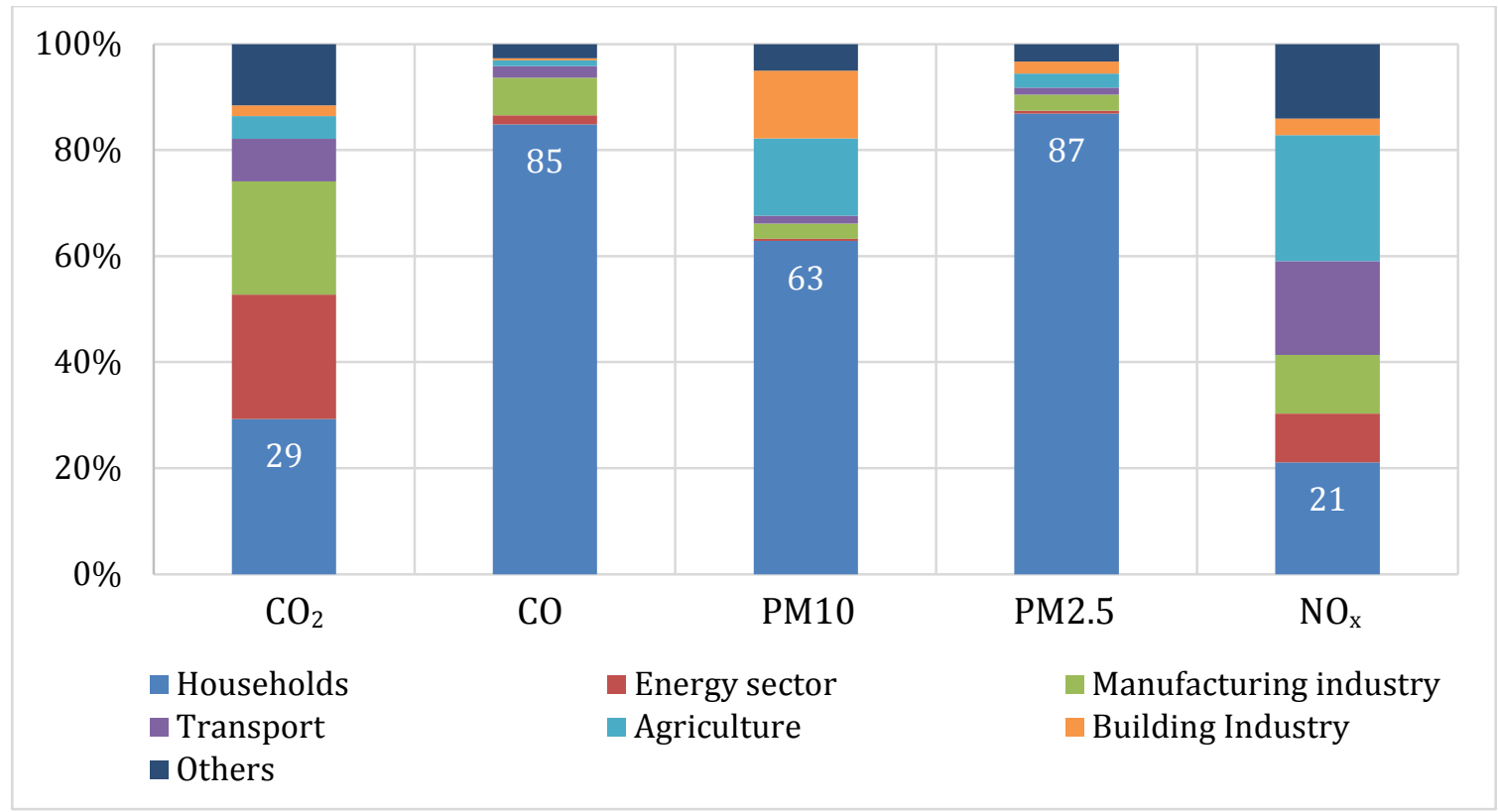

Figure 1. Percentage distribution of air pollutant emissions from Sectors in 2017 in Hungary [16]

Because the residential wood combustion that produces fine particles and hazardous organic compounds that cause air quality problems, there is a need to decrease the particle and gaseous emissions from wood combustion in small scale appliances [15]. In this study, we monitored emission concentrations of $\mathrm{CO}$ and $\mathrm{NOx}, \mathrm{O}_{2}$ of the flue gas during domestic combustion of firewood in a new TOTYA S18 type boiler. The temperature of the flue gas was also monitored. The aim is to optimize the operation of the boiler. Operating the boilers in the correct mode minimizes air pollutant emissions, and the greater part of the heat generated is actually turns to heating the home, as with poor settings, a lot of heat leaves through the chimney.

Beside those measurement, the composition of the emissions from traditional solid fuel-fired boiler, which is widely used, was compared to experimental modern pellet-fired boiler boilers. The data obtained during the tests can also be used to determine whether the boilers comply with the emission values set out in the Regulation.

\section{Material and methods}

The firing experiments were carried out in a TOTYA S18 plate boiler, which is readily available and widely used in Hungary. The boiler has several control options:

- There is a trap door on the ash door where primary combustion air required for combustion flows.

- There is a secondary combustion air outlet on the feeding door.

- A butterfly valve is installed in the chimney to regulate the draft. 
There is a trap door on the door of the boiler, which is moved by a draft regulator with automatic control. The function of the automatic draft regulator is to control the volume flow of primary air based on the temperature of the water in the boiler. The draft regulator uses a chain to open and close the trap door. With larger draft chimneys, the temperature of the flue gas is too high, resulting in high heat loss and reduced boiler efficiency. In this case, an increase in efficiency can be achieved by using a butterfly valve mounted in the chimney. The door on the top of the boiler is used for easier cleaning of the heat exchanger. The measuring system used is shown in Figure 2.

The gaseous composition of the flue gas was studied thanks to a gas analyser PG 250 (HORIBA, KYOTO, JAPAN) which uses different analysis methods: chemiluminescence detectors (NO); Nondispersive infrared sensor $\left(\mathrm{SO}_{2}, \mathrm{CO}, \mathrm{CO}_{2}\right)$; paramagnetic detector $\left(\mathrm{O}_{2}\right)$. The internal water temperature of the boiler was kept close at $60^{\circ} \mathrm{C}$.

During the experiments, the amount of wood added to the firebox varied between 5 and $8 \mathrm{~kg}$ on average. The firewood was chopped to size: cut into quarters and / or eighths of $20-25 \mathrm{~cm}$. It is important that reliable measurements can only start after the "basic ember" has been completed, which takes approximately 1 hour each time.

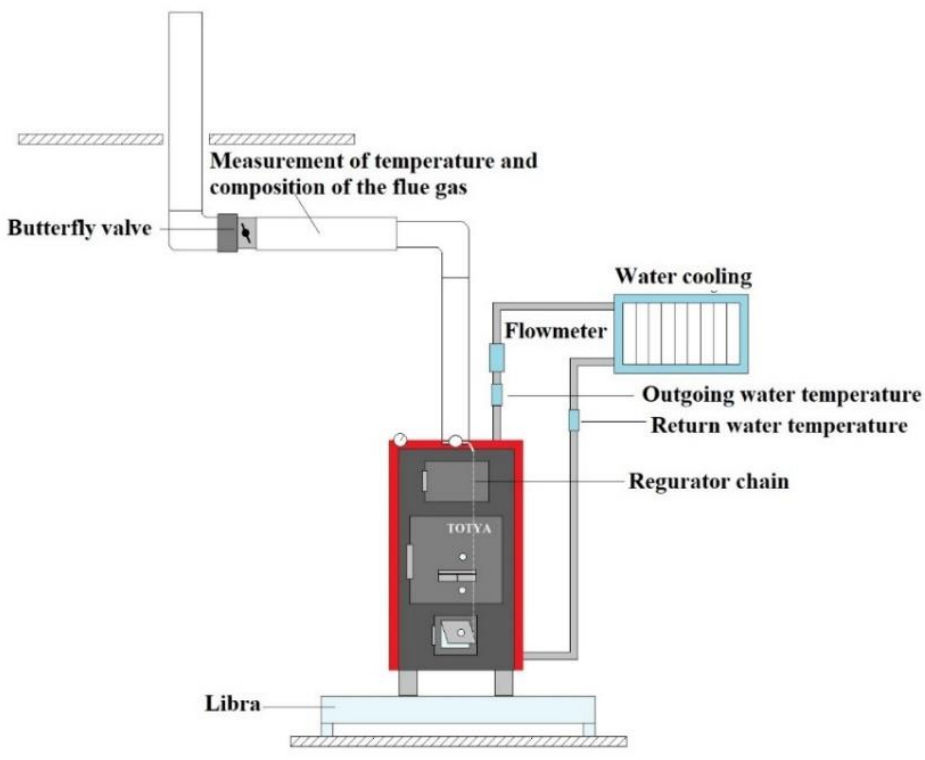

Figure 2. Measuring circle

\section{Results}

In order to evaluate the results obtained during the measurements, the results of an automatic pellet boiler, which is in experimental phase, were also included in the evaluation.

\subsection{The relationship of the temperature of flue gas and amount of $\mathrm{O}_{2}$ and $\mathrm{CO}_{2}$}

Part of the heat in the boiler system is left through the chimney with the flue gases. The maintaining cost can be decreased and the boiler efficiency can be improved by minimizing this loss supplying optimizing excess air ratio [17]. The oxygen trim control system will maintain the optimum air fuel 
ratio, so that the highest possible combustion efficiency could be achieved. With reduced excess air, flue gas volume is also reduced and the temperature of the gas decreases because of reducing gas velocities, allowing gas to spend more time in the boiler where the heat can be absorbed [17] [18].

In the case of pellet firing, the air control system can keep the amount of oxygen constant with the temperature of the flue gas and water during firing. In contrast, the TOTYA boiler, even though it has an automatic air regulator, is highly dependent on the heat exchanger material, where the heat transfer to the water space is not perfect as the temperature of the flue gas went up to $250{ }^{\circ} \mathrm{C}$, even in the best case, with relatively small fluctuations in the temperature (Figure 3).
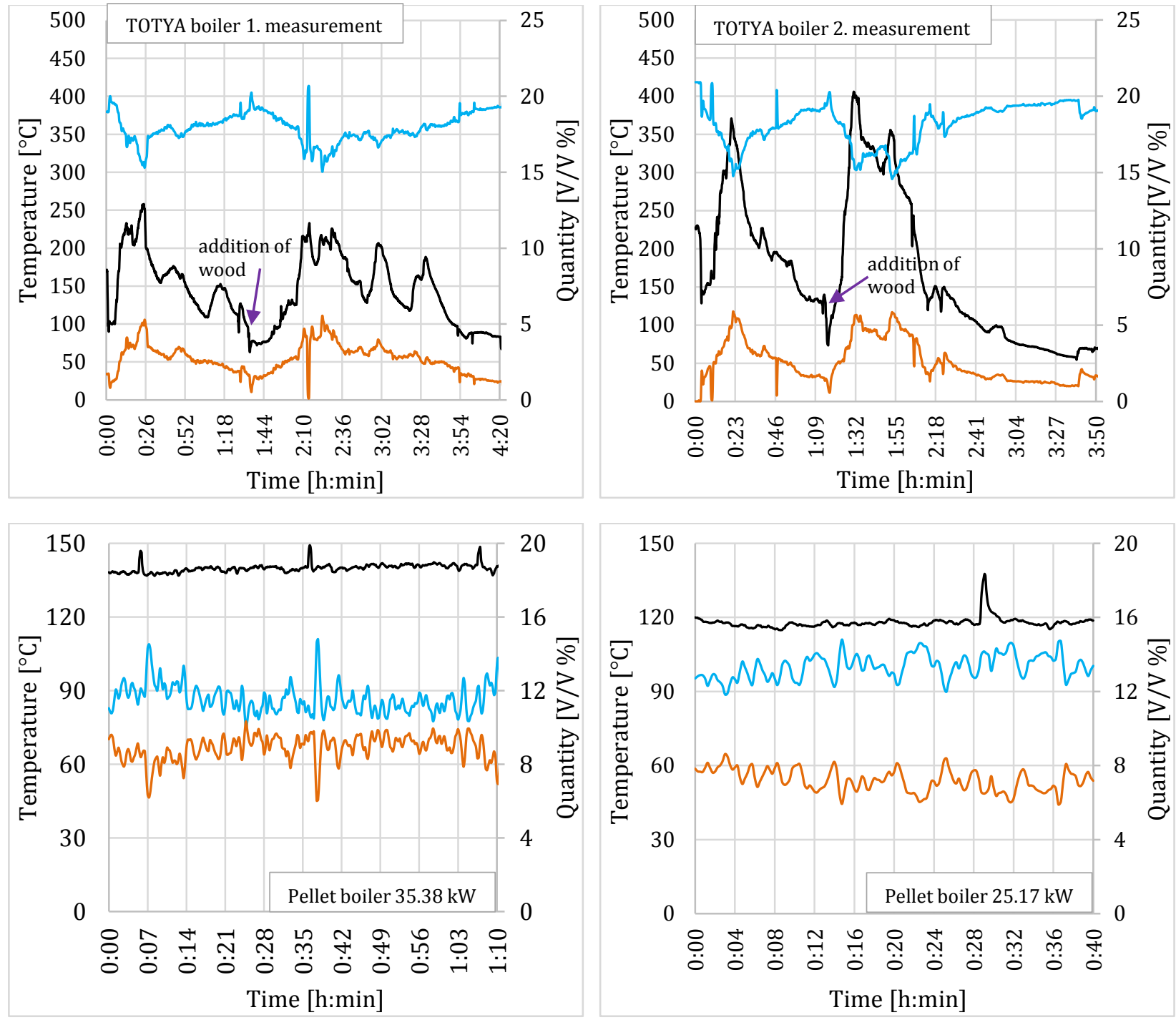

-Temperature of flue gas

- Oxygen

Carbon-dioxide

Figure 3. The relationship of the temperature of flue gas and amount of $\mathrm{O}_{2}$ and $\mathrm{CO}_{2}$

The curves in the diagrams change synchronously with each other, and as the amount of $\mathrm{O}_{2}$ increases, the temperature of the flue gas and the amount of $\mathrm{CO}_{2}$ also decrease. 
In the case of the TOTYA boiler, the intervention points are clearly readable and the firing cycles are separable. After addition (0:00, and at the time indicated by the arrow), the flue gas temperature curve of Measurement 1 shows several peaks, which can be explained by the fact that the flames get caught in the still intact wood layers; and as the water temperature drops, the automation opened the primary air outlet. In the case of the second measurement, these peaks are smaller, since the heat exchanger operated during the whole measurement, while in the first measurement it only operated periodically.

After the fuel is added, the temperature of the flue gas decreases and the amount of $\mathrm{O}_{2}$ increases. Tissari et. al. have been reported similar results [15]. After inflammation of the wood pile, the $\mathrm{O}_{2}$ content of the flue gas decreases, as more intense combustion demands more $\mathrm{O}_{2}$. This indicates the effectiveness of the burn. When the wood pile is burned down, the $\mathrm{O}_{2}$ content of the flue gas increases again and the temperature decreases. The concentration of $\mathrm{CO}_{2}$ increases during the first 20-25 minutes after addition the wood, when it reaches the highest concentration and lowest amount of $\mathrm{O}_{2}$ in the flue gas [19]. In contrast, the pellet boiler was fed continuously with pellet fuel.

$\mathrm{CO}_{2}$ emissions are typically higher in the case of modern boilers. While the TOTYA boiler did not exceed $6 \mathrm{~V} / \mathrm{V} \%$ of the $\mathrm{CO}_{2}$, the pellet boiler was $8-9 \mathrm{~V} / \mathrm{V} \%$. The increased amount of $\mathrm{CO}_{2}$ indicates the efficiency of the combustion. 


\subsection{Relationship of amount of $\mathrm{NO}_{\mathrm{x}}-\mathrm{CO}-\mathrm{CO}_{2}$ in the flue gas}

The aim of combustion is to convert the fuel into heat and the carbon contained in the fuel into $\mathrm{CO}_{2}$. If the conversion is not perfect the combustion process will end on some intermediate combustion products like CO [10]. CO is a toxic gas pollutant whose emission is a result of the incomplete combustion due to low burning temperature, insufficient oxygen, poor mixing of fuel with the combustion air and/or too short residence time of the combustion gases in the combustion zone [20] .
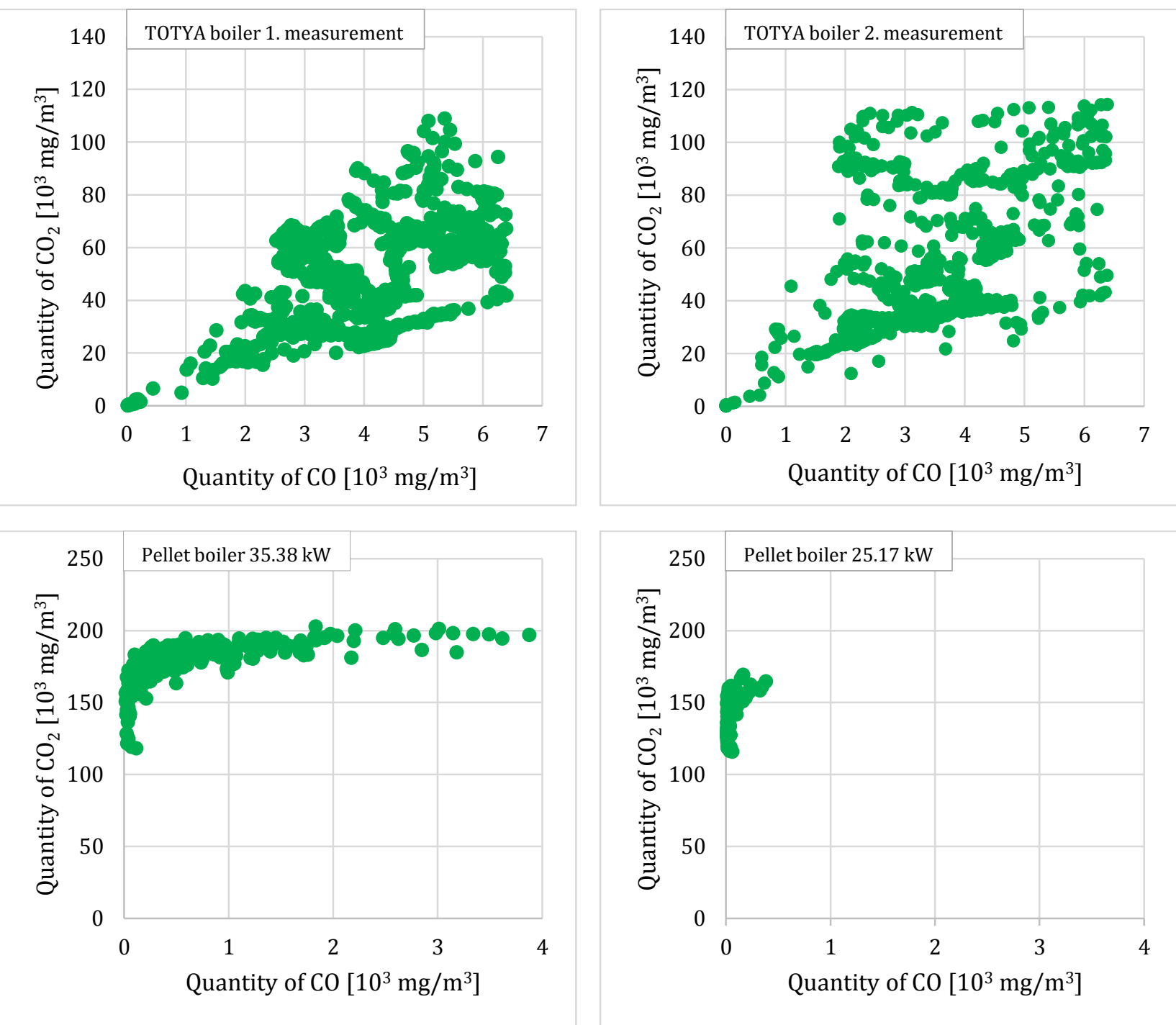

Figure 4. Connection of $\mathrm{CO}$ and $\mathrm{CO}_{2}$

At high load (lower excess oxygen), mixing limitations increase the CO emissions. The higher excess oxygen corresponds to lower load, decreasing gas temperature and thus yielding more $\mathrm{CO}$ emissions [21]. Although $\mathrm{CO}$ is a product of incomplete combustion, its concentration could not reflect the extent of incomplete combustion that is associated with $\mathrm{CO}_{2}$ concentration [22].

Since CO is influenced by several factors, there is no clear relationship between $\mathrm{CO}$ and $\mathrm{CO}_{2}$. An increased ventilation rate may promote $\mathrm{CO}_{2}$ formation by increasing the oxygen supply, but may also restrict the modified combustion efficiency and therefore $\mathrm{CO}_{2}$ emission by reducing the combustion 
temperature. An excess of air may improve mixing but may decrease the residence time and combustion temperature [23]. The less $\mathrm{CO}$ is in the system and the less the standard deviation of the $\mathrm{CO}-\mathrm{CO}_{2}$ function, the more certain the combustion is near to the perfect (Figure 4).
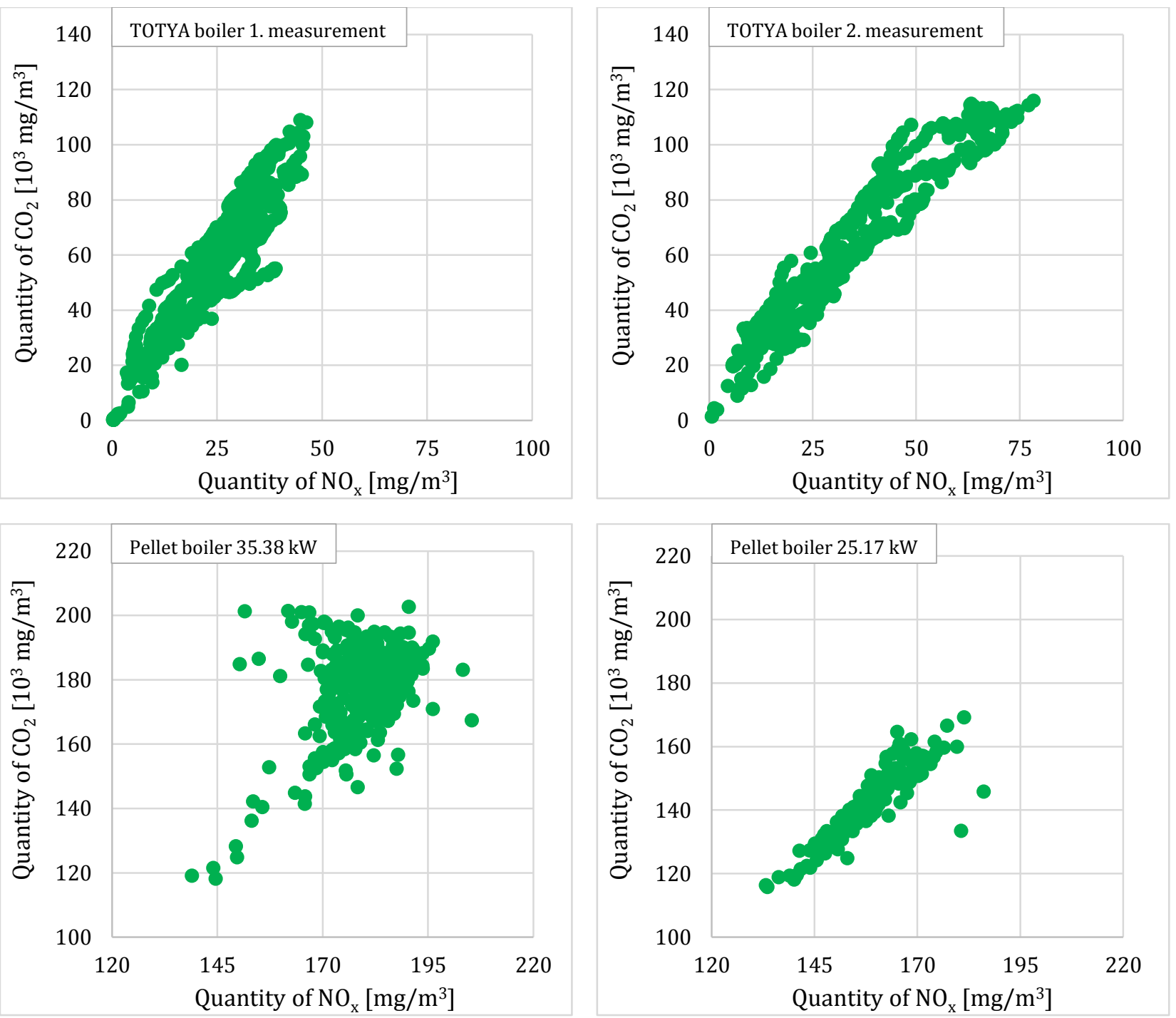

Figure 5. Connection of $\mathrm{NO}_{x}$ and $\mathrm{CO}_{2}$

In this study, NOx was measured as the sum of nitrogen monoxide (NO) and nitrogen dioxide $\left(\mathrm{NO}_{2}\right)$. The three main reasons for $\mathrm{NO}_{\mathrm{x}}$ formation during biomass combustions are: thermal $\mathrm{NO}_{\mathrm{x}}$ (formed from atmospheric nitrogen, above $1300{ }^{\circ} \mathrm{C}$ ), the prompt $\mathrm{NO}_{\mathrm{x}}$ (formed at the flame front) and the fuel- $\mathrm{NO}_{\mathrm{x}}$ (formed from elemental nitrogen contents of the fuel) [24]. For biomass combustion at temperatures below $1300^{\circ} \mathrm{C}$, which is usually the case for small domestic stoves, $\mathrm{NO}_{\mathrm{x}}$ is expected to be formed from nitrogen constituent of the fuels [20]. Thus the nitrogen content of the fuel are major influencing factors for NOx emission in solid fuel combustion, respectively [10].

If the burn is complete, the energy release will be maximized. The more energy released per unit time, the more $\mathrm{NO}_{\mathrm{x}}$ there will be in the system. In parallel, the $\mathrm{C}$ content of the fuel is converted to $\mathrm{CO}_{2}$, the amount of which can only be influenced by the degree of air-fuel mixing. Regardless of the type of boiler, there is a clear linear relationship between the amount of $\mathrm{CO}_{2}$ and $\mathrm{NO}_{\mathrm{x}}$ (Figure 5). 


\subsection{Emissions covered by the EU Regulation}

The experiments show that the $\mathrm{CO}$ emissions increased to high levels in conjunction with the decrease in $\mathrm{NO}_{\mathrm{x}}$ [25]. From Figure 6, in case of conventional boiler the NOx emissions showed that the concentrations increased after the addition of wood, arrived at a high level, and decreased gradually after burning for a period of time. The amount of $\mathrm{CO}$ decreases with the increase of $\mathrm{NO}_{\mathrm{x}}$ emissions.
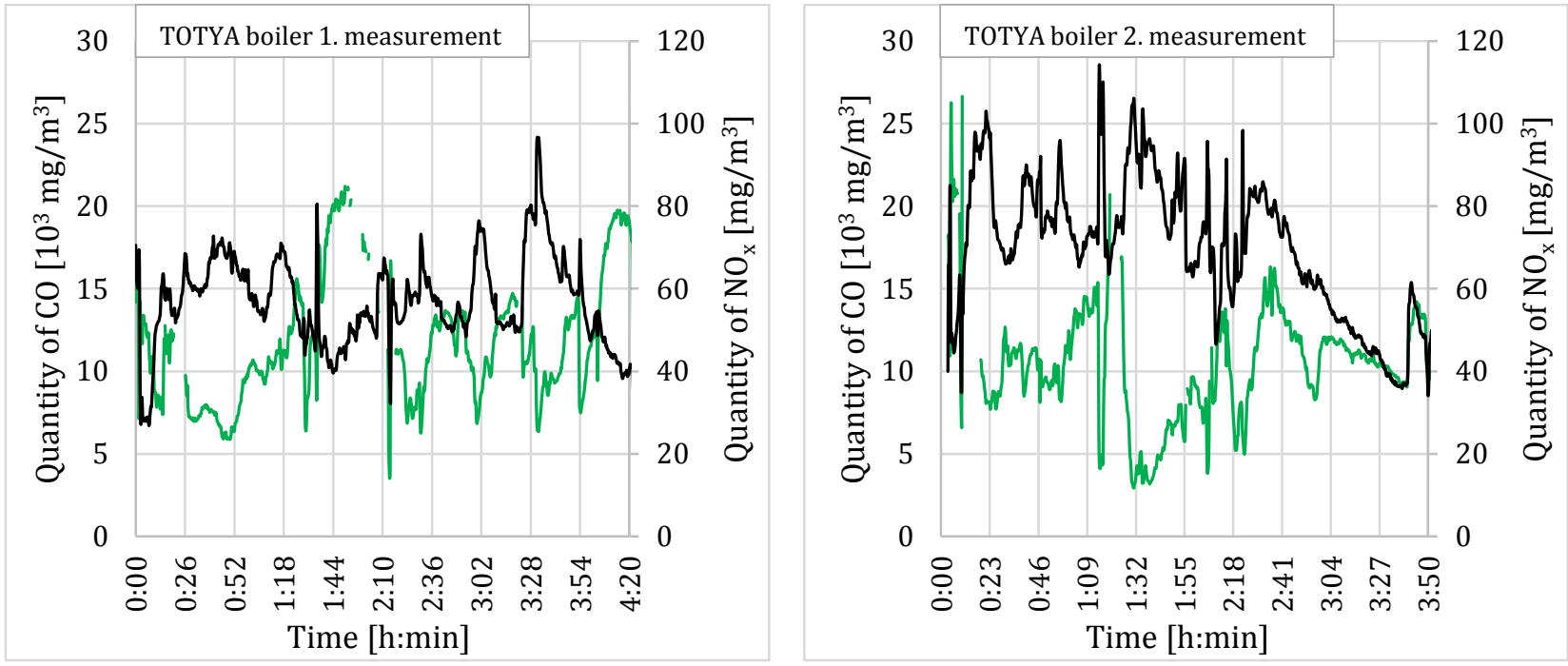

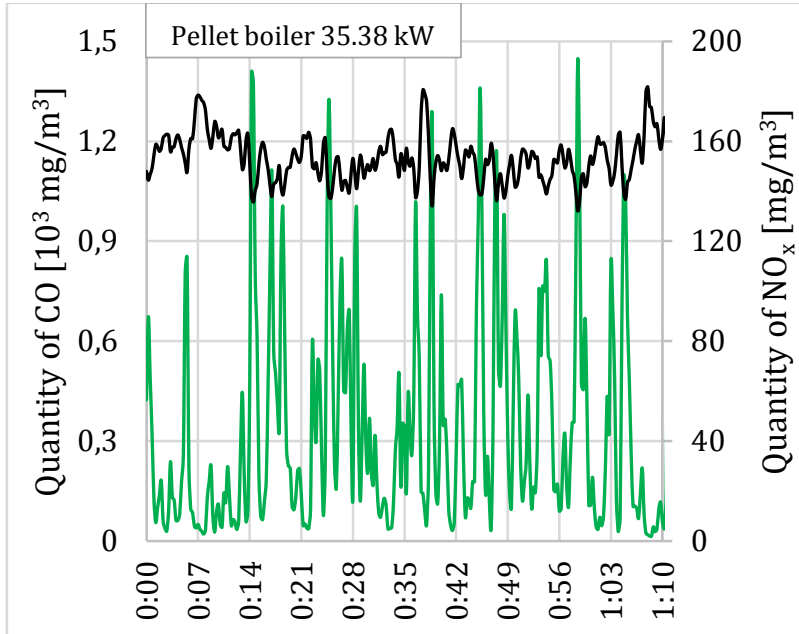

Time [h:min]

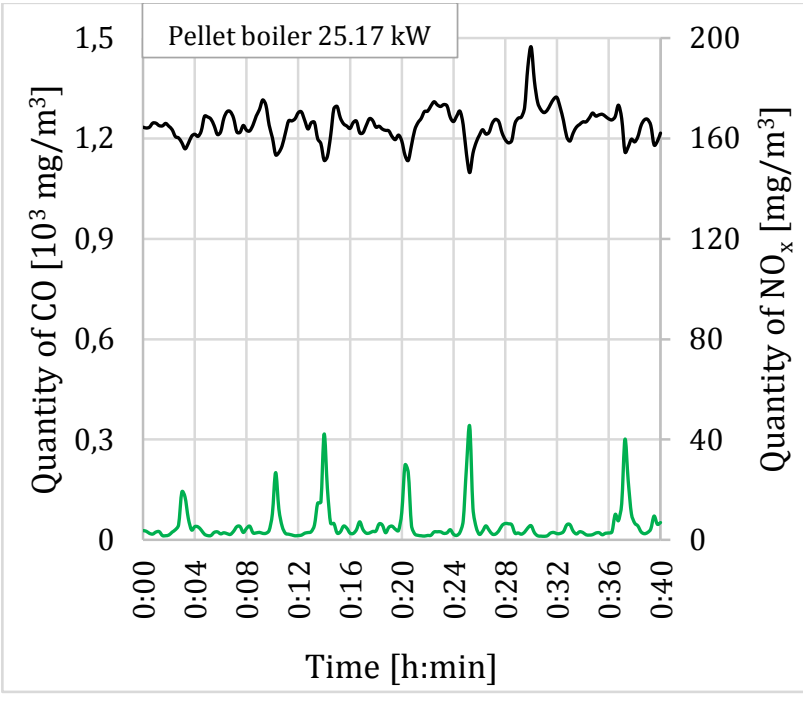

Nitrogen-oxides

Figure 6. Emission of $\mathrm{NO}_{x}$ and $\mathrm{CO}$ during combustion $\left(13 \% \mathrm{O}_{2}\right)$

Higher combustion temperatures promote $\mathrm{NO}_{\mathrm{x}}$ formation. At low temperatures, less combustion air enters the system, fuel-air mixing deteriorates, combustion becomes imperfect, and CO emissions increase.

According to the decree, which will come into force on January 1, 2022, the CO emissions of firewood, closed-fired chamber, solid-fueled, individual space heaters should not exceed $1500 \mathrm{mg} / \mathrm{m}^{3}$, while for pellet-fired wood, $300 \mathrm{mg} / \mathrm{m}^{3}\left(13 \%\right.$ with $\left.\mathrm{O}_{2}\right)$. 
During operation of the traditional TOTYA combustion plant, even in the case of stable combustion, CO emissions were exceeded in almost one hundred percent of the cases according to the regulation. In the case of pellet firing, the limit was exceeded only when the boiler was operated at higher capacity.

It can be stated that the pellet boiler with better combustion has increased $\mathrm{NO}_{\mathrm{x}}$ emission compared to the TOTYA boiler, but this value did not reach the limit set in the regulation.

\section{Conclusion}

In this study, we monitored emission concentrations of $\mathrm{CO}$ and $\mathrm{NO}_{\mathrm{x}}, \mathrm{O}_{2}$ and temperature of the flue gas during domestic combustion of firewood in a new TOTYA S18 type boiler. In order to evaluate the results obtained during the measurements, the results of an automatic pellet boiler, which is in experimental phase, were also included in the evaluation.

In the case of the TOTYA boiler, the combustion cycles are well separated; if the $\mathrm{O}_{2}$ content is high, the temperature of the flue gas and the amount of $\mathrm{CO}_{2}$ are low. The $\mathrm{O}_{2}, \mathrm{CO}_{2}$ content and temperature of the flue gas remain relatively constant during pellet boiler operation. $\mathrm{CO}_{2}$ emissions are typically higher in the case of modern boilers. While the TOTYA boiler did not exceed $6 \mathrm{~V} / \mathrm{V} \%$ of $\mathrm{CO}_{2}$, the pellet boiler was 8-9 V/V \%. The increased amount of $\mathrm{CO}_{2}$ indicates the efficiency of the combustion.

Since CO is influenced by several factors, there is no clear relationship between $\mathrm{CO}$ and $\mathrm{CO}_{2}$. The less $\mathrm{CO}$ is in the system and the smaller the standard deviation on the function of $\mathrm{CO}-\mathrm{CO}_{2}$, the more certain that combustion is nearing perfect.

The more energy released per unit time, the more $\mathrm{NO}_{\mathrm{x}}$ there will be in the system. In parallel, the $\mathrm{C}$ content of the fuel is converted to $\mathrm{CO}_{2}$, the amount of which can only be influenced by the degree of air-fuel mixing. Regardless of the type of boiler, there is a clear linear relationship between the amount of $\mathrm{CO}_{2}$ and $\mathrm{NO}_{\mathrm{x}}$

During operation of the traditional TOTYA combustion plant, even in the case of stable combustion, the $\mathrm{CO}$ emission exceeded the value in the decree in almost one hundred percent of the cases. In the case of pellet firing, the limit was exceeded only when the boiler was operated at higher capacity. It can be stated that the pellet boiler with better combustion has increased $\mathrm{NO}_{\mathrm{x}}$ emission compared to the TOTYA boiler, but this value did not reach the limit set in the regulation. The decree, which will come into force on January 1, 2022, applies to newly purchased boilers, but in poorer regions the people cannot buy new boilers, so in the most households malfunctioning firing equipments are stayed.

\section{References}

[1] EURÓPAI BIZOTTSÁG, “A BIZOTTSÁG KÖZLEMÉNYE AZ EURÓPAI PARLAMENTNEK, A TANÁCSNAK, AZ EURÓPAI GAZDASÁGI ÉS SZOCIÁLIS BIZOTTSÁGNAK ÉS A RÉGIÓK BIZOTTSÁGÁNAK," 2018.

[2] Európai Számvevőszék, “Légszennyezés: egészségünk védelme még mindig nem elégséges,” 2018. [Online]. Available: https://www.eca.europa.eu/Lists/ECADocuments/SR18_23/SR_AIR_QUALITY_HU.pdf. [Accessed: 08-May-2019]. 
[3] B. Brandelet, C. Rose, C. Rogaume, and Y. Rogaume, "Impact of ignition technique on total emissions of a firewood stove," Biomass and Bioenergy, vol. 108, pp. 15-24, Jan. 2018.

[4] H. A. C. Denier van der Gon et al., "Particulate emissions from residential wood combustion in Europe - revised estimates and an evaluation," Atmos. Chem. Phys., vol. 15, no. 11, pp. 65036519, Jun. 2015.

[5] S. Ozgen et al., "Analysis of the chemical composition of ultrafine particles from two domestic solid biomass fired room heaters under simulated real-world use," Atmos. Environ., vol. 150, pp. 87-97, Feb. 2017.

[6] M. Glasius et al., "Impact of wood combustion on particle levels in a residential area in Denmark," Atmos. Environ., vol. 40, no. 37, pp. 7115-7124, Dec. 2006.

[7] L. S. Johansson, B. Leckner, L. Gustavsson, D. Cooper, C. Tullin, and A. Potter, "Emission characteristics of modern and old-type residential boilers fired with wood logs and wood pellets," Atmos. Environ., vol. 38, no. 25, pp. 4183-4195, Aug. 2004.

[8] "Commission Regulation (EU) 2015/1185 implementing Directive 2009/125 EC of the European Parliament and of the Council with regard to ecodesign requirements for solid fuel local space heaters," Off. J. Eur. Union, pp. 1-19, 2015.

[9] E. D. Vicente, M. A. Duarte, A. I. Calvo, T. F. Nunes, L. Tarelho, and C. A. Alves, "Emission of carbon monoxide, total hydrocarbons and particulate matter during wood combustion in a stove operating under distinct conditions," Fuel Process. Technol., vol. 131, pp. 182-192, Mar. 2015.

[10] K. Křůmal, P. Mikuška, J. Horák, F. Hopan, and K. Krpec, "Comparison of emissions of gaseous and particulate pollutants from the combustion of biomass and coal in modern and old-type boilers used for residential heating in the Czech Republic, Central Europe," Chemosphere, vol. 229, pp. 51-59, Aug. 2019.

[11] O. Sippula, K. Hytönen, J. Tissari, R. Taisto, and J. Jorma, "Effect of Wood Fuel on the Emissions from a Top-Feed Pellet Stove," Energy Fuels, vol. 21, no. 2, pp. 1151-1160, 2007.

[12] H. Lamberg, O. Sippula, J. Tissari, and J. Jokiniemi, "Effects of Air Staging and Load on FineParticle and Gaseous Emissions from a Small-Scale Pellet Boiler," Energy \& Fuels, vol. 25, no. 11, pp. 4952-4960, Nov. 2011.

[13] T. Nussbaumer, "Combustion and Co-combustion of Biomass: Fundamentals, Technologies, and Primary Measures for Emission Reduction," Energy Fuels, vol. 17, no. 6, pp. 1510-1521, 2003.

[14] V. K. Verma, S. Bram, and J. De Ruyck, "Small scale biomass heating systems: Standards, quality labelling and market driving factors - An EU outlook," Biomass and Bioenergy, vol. 33, no. 10, pp. 1393-1402, Oct. 2009.

[15] J. Tissari et al., "Fine particle and gaseous emissions from normal and smouldering wood combustion in a conventional masonry heater," Atmos. Environ., vol. 42, no. 34, pp. 7862-7873, Nov. 2008.

[16] “Központi Statisztikai Hivatal-Nemzetgazdasági ágak és háztartások kibocsátása." [Online]. Available: https://www.ksh.hu/stadat_eves_5. [Accessed: 11-Oct-2019].

[17] M. C. Barma, R. Saidur, S. M. A. Rahman, A. Allouhi, B. A. Akash, and S. M. Sait, "A review on boilers energy use, energy savings, and emissions reductions," Renew. Sustain. Energy Rev., vol. 79, pp. 970-983, Nov. 2017.

[18] I. Kilicaslan and E. Ozdemir, "Energy economy with a variable speed drive in an oxygen trim controlled boiler house," J. Energy Resour. Technol. Trans. ASME, vol. 127, no. 1, pp. 59-65, 2005. 
[19] J. Jimenez, O. Farias, R. Quiroz, and J. Yañez, "Emission factors of particulate matter, polycyclic aromatic hydrocarbons, and levoglucosan from wood combustion in south-central Chile," J. Air Waste Manage. Assoc., vol. 67, no. 7, pp. 806-813, Jul. 2017.

[20] M. Xiu, S. Stevanovic, M. M. Rahman, A. M. Pourkhesalian, L. Morawska, and P. K. Thai, "Emissions of particulate matter, carbon monoxide and nitrogen oxides from the residential burning of waste paper briquettes and other fuels," Environ. Res., vol. 167, pp. 536-543, Nov. 2018.

[21] M. M. Roy, A. Dutta, and K. Corscadden, "An experimental study of combustion and emissions of biomass pellets in a prototype pellet furnace," Appl. Energy, vol. 108, pp. 298-307, Aug. 2013.

[22] M. Deng et al., "Real-time combustion rate of wood charcoal in the heating fire basin: Direct measurement and its correlation to CO emissions," Environ. Pollut., vol. 245, pp. 38-45, Feb. 2019.

[23] W. Wei et al., "Emissions of carbon monoxide and carbon dioxide from uncompressed and pelletized biomass fuel burning in typical household stoves in China," Atmos. Environ., vol. 56, pp. 136-142, Sep. 2012.

[24] M. M. Roy and K. W. Corscadden, "An experimental study of combustion and emissions of biomass briquettes in a domestic wood stove," Appl. Energy, vol. 99, pp. 206-212, Nov. 2012.

[25] A. Lyngfelt and B. Leckner, "Combustion of wood-chips in circulating fluidized bed boilers - NO and CO emissions as functions of temperature and air-staging," Fuel, vol. 78, no. 9, pp. 10651072, Jul. 1999. 